\title{
Peran Perguruan Tinggi Dalam Meningkatkan Sistem Pertahanan Negara Melalui Pendidikan Bela Negara
}

\author{
(The Role Of Universities In Improving The National Defense \\ System Through State Education)
}

\author{
Holimin $^{\text {1*, }}$ Dartono $^{2}$, Djoko Prihantoro ${ }^{3}$ \\ 1,2,3 Dosen dan Instruktur Akademi Angkatan Udara, Yogyakarta, Indonesia \\ E-mail: holimin@aau.ac.id,dartono@aau.ac.id,djoko_prihantoro@aau.ac.id
}

\begin{abstract}
The process of globalization and advances in information technology have caused major changes in the lives of the world's people. Access to information is getting easier and faster to spread throughout the country, creating global transparency where the physical boundaries of a country's sovereignty do not seem to exist, thus presenting a world without borders. Advances in technology have encouraged the formation of an increasingly transparent and open world society. This openness provides opportunities for interdependence between nations, and often leads to competition. The high level of competence can lead to an increase in the interests of a country against other countries. Indonesia as an independent and sovereign country with abundant natural resources and human resources, needs to develop awareness of state defense in the form of increasing national defense capabilities through the participation of universities, both in developing defense equipment through research and developing human resources as a defense force. The mandate of the Constitution in article 27 paragraph (3) states that every citizen has the right and is obliged to participate in efforts to defend the state. Every citizen has the right and is obliged to participate in national defense and security efforts (Article 30 paragraph 1) and Article 2 states that state defense and security is carried out through a universal people's defense and security system in which the Indonesian National Armed Forces and the Indonesian National Police are the main forces, and the people as a supporting force. Observing the constitutional order requires the role of universities in developing their contribution to the development and development of the national defense system. There is a need for a mechanism of cooperation between the Ministry of Defense and the Ministry of Education and Culture in general as well as cooperation between TNI units related to Higher Education as providers of higher education.
\end{abstract}

Keywords - Global Competition, Role of Universities, Defense System PS

Abstrak- Proses globalisasi dan kemajuan teknologi informasi telah menimbulkan perubahan besar dalam kehidupan masyarakat dunia. Akses informasi semakin mudah dan cepat menyebar keseluruh negara, menciptakan trasparansi global dimana batas-batas fisik kedaulatan suatu negara seolah-olah tidak ada sehingga menghadirkan dunia tanpa batas. Kemajuan teknologi telah mendorong terbentuknya masyarakat dunia yang makin transparan dan terbuka. Keterbukaan tersebut memberi peluang terjadinya adanya saling ketergantungan antar bangsa, dan tidak jarang mengarah dalam suatu kompetisi. Tingginya tingkat kompetensi dapat mengarah kepada meningkatnya kepentingan suatu negara terhadap negara lain. Indonesia sebagai negara yang merdeka dan berdaulat dengan melimpahnya SDA dan SDM, perlu mengembangkan kesadaran bela negara dalam bentuk meningkatkan kemampuan pertahanan negara melalui peran serta perguruan tinggi baik pengembangan alutsista melalui research maupun pengembangan SDM sebagai kekuatan pertahanan. Amanat Kontitusi pada pasal 27 ayat (3) menyatakan bahwa setiap warganegara berhak dan wajib ikut serta dlm upaya pembelaan negara. Tiap-tiap warga negara berhak dan wajib ikut serta

*Penulis Korespondensi (Holimin)

E-mail:holimin@aau.ac.id 
dalam usaha pertahanan dan keamanan negara (pasal 30 ayat 1) dan pada pasal 2 menyatakan pertahanan dan keamanan negara dilaksanakan melalui sistem pertahanan dan keamanan rakyat semesta dimana TNI dan Kepolisian Negara Republik Indonesia, sebagai kekuatan utama, dan rakyat sebagai kekuatan pendukung. Mencermati perintah konstitusi tersebut dibutuhkan peran Perguruan Tinggi dalam mengembangkan kontribusinya dalam pembangunan dan pengembangan sistem pertahanan negara. Perlu mekanisme kerjasama antara kementrian pertahanan dengan kementrian pendidikan dan kebudayaan secara umum serta kerjasama antara kesatuan kesatuan TNI terkait dengan Perguruan Tinggi sebagai penyelenggara pendidikan tinggi.

Kata Kunci- Persaingan Global, Peran Perguruan Tinggi, Sistem Pertahanan

\section{PENDAHULUAN}

$\mathrm{P}$ roses globalisasi dan kemajuan teknologi informasi dan komunikasi saat ini telah menciptakan trasparansi global dimana batas-batas fisik kedaulatan suatu negara seolah-olah tidak ada, sehingga menghadirkan dunia tanpa batas (borderless world). Proses ini berkembang dari waktu ke waktu sejalan dengan perkembangan ideologi, politik, ekonomi dan sosial budaya. Perkembangan serta kemajuan ilmu pengetahuan teknologi informasi dan komunikasi, telah mendorong hubungan sosial dan saling ketergantungan antarbangsa, antarnegara dan antar manusia semakin besar. Globalisasi yang didominasi oleh kemajuan ilmu pengetahuan dan teknologi informasi, telah merubah pola hubungan antar bangsa dalam berbagai aspek dan menjadikan globalisasi sebagai fenomena yang bersifat multidimensi. Kemajuan dibidang ilmu pengetahuan dan teknologi semakin memudahkan semua aktivitas manusia. Kemajuan teknologi telah mendorong perubahan dalam aspek kehidupan manusia, dengan terbentuknya masyarakat dunia yang makin transparan dan terbuka. Keterbukaan tersebut memberi peluang terjadinya penetrasi nilai-nilai universal yang kemudian berinteraksi dengan nilai-nilai dasar suatu bangsa, sehingga membentuk masyarakat global dengan ciri adanya saling ketergantungan antar negara (interdependency), dan dan saling terhubung (interconected) antara satu negara dengan negara lainnya. Derasnya arus globalisasi membuat banyak negara memilih untuk menancapkan pengaruhnya bukan dengan hard power, namun dengan soft power dan smart power. Soft power dan smart power ini merupakan pengaruh-pengaruh tak tampak namun dapat mengancam negara lain, seperti kekuatan sosial dan ekonomi yang dimiliki oleh suatu negara.[1] Indonesia sebagai negara yang merdeka dan berdaulat perlu mengembangkan kesadaran bela negara untuk menangkal efek negatif penetrasi global dari soft power dan smart power yang tidak dapat dihindarkan guna menjaga keutuhan NKRI.

Perguruan Tinggi merupakan institusi penyelenggaran pendidikan sebagai wadah yang strategis untuk menciptakan dan mengembangkan sistem pertahanan negara melalui pembinaan sumber daya manusia serta ilmu pengetahuan dan teknologi . Mahasiswa sebagai bagian dari kelompok generasi muda, memiliki peran dan tanggung jawab dalam usaha pembelaan negara dan perubahan yang terjadi dalam sejarah bangsa Indonesia.[2] Perguruan tinggi sebagai tempat kaum intelektual, memiliki peran yang penting dalam pengembangan sistem pertahanan negara. Civitas akademika perguruan tinggi memiliki kemampuan untuk mempertahankan tanah air dari ancaman-ancaman bersifat nir militer seperti ancaman politik, ekonomi, sosial, budaya, dan teknologi. Selain itu perguruan tinggi juga dapat menjadi pusat riset teknologi alutsista yang dibutuhkan militer. Namun saat ini peran tersebut dalam bela negara dirasa kurang optimal baik dari sisi pembinaan sumber daya manusia dan pemanfaatan kemampuan Iptek guna mendukung alutsista sistem pertahanan negara.

Mencermati kondisi tersebut di atas, maka diperlukan langkah-langkah untuk mengoptimalkan perguruan tinggi sebagai salah satu sumber membangun sistem pertahanan negara dalam upaya bela negara. Hal ini merupakan panggilan konstitusi sesuai pasal 27 ayat (3) menyatakan bahwa setiap warga negara berhak dan wajib ikut serta dlm upaya pembelaan 
negara. Pada pasal 30 ayat 1 menyatakan tiap-tiap warga negara berhak dan wajib ikut serta dalam usaha pertahanan dan keamanan negara. Dengan demikian dibutuhkan suatu strategi dan langkah-langkah kongkrit berupa perumusan kebijakan, yang melibatkan seluruh komponen bangsa. Penting adanya kerjasama antara kementrian terkait sebagai bentuk payung hukum agar kegiatan tersebut dapat segera terealisasi dengan baik. Dengan payung hukum yang jelas, diharapkan realisasi kerjasama dapat diturunkan ke instansi atau satuan dibawahnya dalam Mou, sehingga dapat dilaksanakan pada tingkat operasional dilapangan. Perlu upaya meningkatkan kesadaran bela negara di Perguruan tinggi melalui pemenuhan kesejahteraan, pendidikan dan latihan, kerjasama dan koordinasi, pengadaan, pemberdayaan, legislasi, revisi, sosialisasi dan penegakkan hukum. Untuk terwujudnya hal tersebut memerlukan dukungan semua pihak dan segenap komponen bangsa, sebagai perwujudan hak dan kewajiban setiap warga negara dalam pembelaan negara. Dengan meningkatkan kesadaran bela negara dikalangan perguruan tinggi diharapkan akan meningkatkan sistem pertahanan negara.

\section{LANDASAN TEORI}

Proses globalisasi dan kemajuan teknologi informasi dan komunikasi berkembang dari waktu ke waktu sejalan dengan perkembangan ideologi, politik, ekonomi dan sosial budaya. Perkembangan serta kemajuan ilmu pengetahuan dan, telah mendorong terjadinya perubahan sosial dan saling ketergantungan antarbangsa, antarnegara dan antar manusia semakin besar. Globalisasi yang didominasi oleh kemajuan ilmu pengetahuan dan teknologi informasi, telah merubah pola hubungan antar manusia dalam berbagai aspek dan menjadikan globalisasi sebagai fenomena yang bersifat multidimensi. Menurut Roy Bhaskar yang dikutip oleh Agus Salim, perubahan sosial biasanya terjadi secara wajar (naturaly), gradual, bertahap serta tidak pernah terjadi secara radikal atau revolusioner.[3] Kemajuan teknologi telah mendorong perubahan dalam aspek kehidupan manusia, dengan terbentuknya masyarakat dunia yang makin transparan dan terbuka. Keterbukaan tersebut memberi peluang terjadinya penetrasi nilai-nilai universal baik positif maupun negatif yang dapat mempengaruhi tata nilai kehidupan bahkan bisa menjadi ancaman bagi bangsa Indonesia. Ancaman adalah setiap usaha dan kegiatan, baik dari dalam negeri maupun luar negeri yang dinilai membahayakan kedaulatan negara, keutuhan wilayah negara, dan keselamatan segenap bangsa.[4] Saat ini, tantangan pertahanan dan keamanan yang dihadapi oleh berbagai negara, termasuk Indonesia, semakin kompleks dan dinamis. Tantangan tersebut dapat datang dari aspek militer, nonmiliter, dan hibrida. Oleh karena itu untuk menghadapi berbagai kemungkinan yang datang, diperlukan penguatan pada sektor pertahanan dan keamanan. Perlu penguatan sistem pertahanan negara dengan sistem pertahanan rakyat semesta yang melibat seluruh warga negara dan sumberdaya nasional melalui pembinaan bela negara meliputi pembinaan SDM dan pengembangan teknologi pertahanan.

\section{Metodologi Penenelitian}

Pada Penulisan naskah ini menggunakan metode penelitian kualitatif, Penelitian kualitatif dilakukan dengan mengumpulkan, menganalisis, dan menafsirkan data non-numerik. Penelitian kualitatif ini diungkapkan dengan kata-kata. Cara penelitian digunakan untuk memahami konsep, pemikiran atau pengalaman. Guna mendapatkan data maka kami lakukan pengumpulan data dengan menggunakan catatan harian, literatur dan berbagai sumber referensi yang relevan dan dibutukan sesuai objek penelitian/penulisan dan dianalisis menggunakan teori dasar atau analisis tematik. 


\section{Pembahasanan}

\section{A. Sistem Pertahanan Semesta dan Bela Negara}

Pertahanan negara adalah usaha untuk mewujudkan satu kesatuan pertahanan negara guna mencapai tujuan nasional, yaitu untuk melindungi segenap bangsa dan seluruh tumpah darah Indonesia, memajukan kesejahteraan umum, mencerdaskan kehidupan bangsa dan ikut serta melaksanakan ketertiban dunia yang berdasarkan kemerdekaan, perdamaian abadi, dan keadilan sosial. usaha pertahanan negara dilaksanakan dengan membangun, memelihara, mengembangkan, dan menggunakan kekuatan pertahanan negara berdasarkan prinsip-prinsip demokrasi, hak asasi manusia, kesejahteraan umum, lingkungan hidup, ketentuan hukum nasional, hukum internasional dan kebiasaan internasional, serta prinsip hidup berdampingan secara damai[5]. Pada hakekatnya pertahanan negara Republik Indonesia adalah segala upaya pertahanan bersifat semesta yang penyelenggaraannya didasarkan pada kesadaran atas hak dan kewajiban warga negara serta keyakinan pada kekuatan sendiri.[6] Sebagai penjabaran konstitusi pada aspek pertahanan, bangsa Indonesia telah menyusun Undang-Undang Nomor 3 Tahun 2002 tentang pertahanan negara yang menetapkan bahwa sistem pertahanan negara bersifat semesta yang melibatkan seluruh warga negara, wilayah, dan sumber daya nasional lainnya, serta dipersiapkan secara dini oleh pemerintah dan diselenggarakan secara total, terpadu, terarah, dan berlanjut untuk menegakkan kedaulatan negara, keutuhan wilayah, dan keselamatan segenap bangsa dari segala ancaman.[7] Hal ini merupakan upaya untuk menyinergikan kinerja komponen militer dan nir militer dalam rangka menjaga, melindungi dan memelihara kepentingan nasional Indonesia. Sistem pertahanan semesta memadukan pertahanan militer dan pertahanan nir militer yang saling mendukung dalam menegakkan kedaulatan negara, keutuhan wilayah NKRI dan keselamatan segenap bangsa dari segala ancaman. Dalam UU RI Nomor 3 tersebut ditegaskan bahwa sebagai wujud dari kesemestaan, pelibatan seluruh warga negara dalam upaya bela negara merupakan kewajiban sekaligus haknya. Sistem Pertahanan Semesta dilaksanakan dengan melibatkan seluruh warga negara, wilayah, serta segenap sumber daya nasional yang dipersiapkan secara dini oleh pemerintah dan diselenggarakan secara total, terpadu, terarah, dan berlanjut. Perkembangan lingkungan strategis yang dinamis saat ini dapat mempengaruhi penyelenggaraan pertahanan negara. Dinamika yang perlu dicermati saat ini adalah pertumbuhan ekonomi yang berimplikasi pada perkembangan kekuatan militer khususnya di kawasan Asia Pasifik. Selain hal tersebut munculnya ancaman non-tradisional seperti terorisme, penggunaan senjata pemusnah massal, spionase, masih akan mewarnai dalam penyelenggaraan pertahanan negara. Kondisi dalam negeri juga terdampak dari pengaruh lingkungan dan konteks strategis yang dipicu oleh situasi dan kondisi ideologi, politik, ekonomi, sosial budaya, dan keamanan. Perkembangan ini dapat menimbulkan adanya ancaman dan tantangan yang berpengaruh terhadap stabilitas dan keamanan serta penyelenggaraan pertahanan negara di Indonesia. Kebijakan pertahanan negara mencakup pembangunan, pengerahan, maupun pemberdayaan pertahanan negara yang didukung kebijakan penganggaran dan pengawasan. Pelaksanaannya secara terpadu dan terarah bagi segenap komponen pertahanan negara, baik Pertahanan Militer maupun Pertahanan Nirmiliter.[8, hlm. 49] Dalam UU nomor 3 tahun 2002 tentang pertahanan negara menempatkan TNI sebagai komponen utama. Sedangkan komponen cadangan dan komponen pendukung merupakan warga negara, SDA, SDB, sarana dan prasarana nasional. Keberadaan komponen cadangan dan komponen pendukung harus dipandang sebagai wadah dan sarana menyalurkan energi kolektif bangsa agar sikap militansi dalam membela negara tidak berkembang menjadi sikap anarkis yang merusak langkah diplomasi Indonesia secara keseluruhan. Melalui pemahaman komprehensif inilah, bela negara dalam spektrum yang lebih keras dapat terselenggara dengan proposional sehingga mampu memperbesar dan memperkuat komponen utama, yang perlu dipahami, spektrum bela negara mulai dari spektrum lunak hingga spektrum keras merupakan spektrum bela negara yang tidak terputus dan berkelanjutan. Komponen cadangan adalah sumber daya nasional yang telah disiapkan untuk dikerahkan 
melalui mobilisasi guna memperbesar dan memperkuat kekuatan dan kemampuan komponen utama. Pembentukan komponen cadangan dari sumber daya nasional diselenggarakan dengan memperhatikan keseimbangan antara hak-hak sipil dan kewajiban warga negara dalam usaha pertahanan negara. Presiden Jokowi menegaska pada upacara penetapan komponen cadangan tahun 2021 bahwa" komponen cadangan tidak boleh digunakan untuk lain kecuali kepentingan pertahanan. Komponen cadangan hanya untuk kepentingan pertahanan dan kepentingan negara".[9] Komponen Pendukung adalah sumber daya nasional termasuk sumber daya manusia yang dapat digunakan untuk meningkatkan kekuatan dan kemampuan Komponen Utama dan Komponen Cadangan dalam menghadapi ancaman militer. Pembentukan Komponen Pendukung dengan memanfaatkan kondisi sumber daya alam dan buatan, sinkronisasi pembangunan sarana, prasarana nasional terhadap kepentingan pertahanan, partisipasi masyarakat madani dalam penyusunan kebijakan pertahanan negara, komponen bela negara masyarakat, dukungan mutualisme industri strategis pertahanan negara baik secara langsung maupun kemampuan konversi industri, serta keberlanjutan pembiayaan pertahanan negara melalui pengelolaan keuangan negara. Menurut penjelasan pasal 9 ayat (1) huruf a UndangUndang Nomor 3 tahun 2002, Bela negara adalah sikap dan prilaku warga negara yang dijiwai oleh kecintaannya kepada NKRI yang berdasarkan Pancasila dan UUD 1945 dalam menjamin kelangsungan hidup bangsa dan negara[10]. Bela negera merupakan konsep yang diatur oleh undang-undang dan disusun oleh pejabat atau petinggi negara tentang patriotisme seseorang, kelompok atau seluruh komponen negara dalam kepentingan mempertahankan eksistensi negara tersebut. Pada UUD 1945 pasal 27 ayat (3) dan pasal 30 ayat (1) menyatakan bahwa setiap warga negara berhak dan wajib ikut serta dalam upaya pembelaan negara. Sehingga dari amanat UUD 1945 dan UU nomor 3 tahun 2002, bela negara selain menjadi kewajiban dasar manusia, juga merupakan suatu kehormatan bagi setiap warga negara yang dilaksanakan dengan penuh kesadaran dan tanggungjawab serta sikap rela berkorban dalam pengabdian kepada negara dan bangsa. Indonesia merupakan negara kepulauan dengan wilayah laut yang sangat luas. Secara geopolitik dan geostrategis, Indonesia terletak pada posisi strategis dan menentukan dalam tata pergaulan global dan regional. Akibatnya, potensi ancaman luar negeri untuk Indonesia sangat tinggi. Wilayah Indonesia yang sangat luas dihuni oleh ratusan juta penduduk dengan latar belakang suku, agama, ras, budaya, dan adat istiadat, kondisi sosial, ekonomi dan politik yang beragam. Keadaan ini sangat rentan terhadap konflik horizontal sehingga potensi ancaman dari dalam negeri pun sangat tinggi. Oleh karena itu, bangsa Indonesia memerlukan kemampuan sistem pertahanan dan keamanan negara yang kuat untuk menjamin tetap tegaknya kedaulatan NKRI. Inilah alasan pentingnya usaha bela negara di Indonesia. Bela negara ini penting bagi negara indonesia, dikarenakan setiap warga negara tentunya mencintai negaranya sehingga perlu untuk menjaganya. Selain itu bela negara diperlukan karena perkembangan ilmu pengetahuan dan teknologi sangat pesat sehingga tantangan negarapun semakin besar, diantaranya perkembangan teknologi 4.0, terorisme global, perubahan iklim perangan dingin antara Cina dan Amerika serikat, narkoba, perdagangan manusia dan lain lain. Dari dalam negri berbagai masalah perlu perhatian khusus seperti permasalahan korupsi yang semakin kronis, rendahnya kualitas SDM dan pendidikan, permasalahan pengakkan hukum dan prilaku masyarakat akibat modernisasi dan globalisasi serta banyak lagi terkait nasionalisme dan rasa persatuan. Guna mewujudkan tujuan dan cita ciata negara, maka diperlukan upaya keras untuk mengatasi permasalahan di atas dengan berbagai solusi jitu, inovatif dan berkelanjutan, bila perlu dengan cara yang diluar pakem yang selama ini berlaku. Tentunya sosialisasi dan pelatihan bela negara menjadikannya salah satu solusi yang harus dilaksanakan, apalagi itu merupakan amanat konstitusi.

\section{B. Perguruan Tinggi dan Bela Negara}

Perguruan Tinggi adalah satuan pendidikan yang menyelenggarakan pendidikan tinggi. Pendidikan Tinggi adalah jenjang pendidikan setelah pendidikan menengah yang mencakup program diploma, program sarjana, program magister, program doktor, dan program profesi, serta program spesialis, yang diselenggarakan oleh perguruan tinggi berdasarkan kebudayaan 
bangsa Indonesia.[11] Perguruan tinggi sebagai salah satu institusi yang terdiri dari kaum intlektual sangat dibutuhkan sebagai mesin pelaksana bela negara dan menjadi ujung tombak yang sangat penting. Perguruan tinggi sebagai cetre of excellent, tempat pengemblengan generasi muda yang berkualitas dan semangat yang tinggi. Oleh karenanya perlu peran aktif perguruan tinggi dalam memajukan sistem pertahanan negara melalui penyelenggaraan bela negara. Perguruan tinggi memiliki peran penting tidak hanya menjadi motor penghasil sumber daya manusia yang berkualitas juga harus mampu melakukan pengembangan tekhnologi yang dikuasai oleh industri pertahanan, khususnya dalam hal memberikan masukan secara akademis pada kebijakan dan inovasi teknologi. beberapa upaya yang harus dilakukan adalah pemantapan sinergitas dan kerja sama antara perguruan tinggi dengan industri pertahanan dalam kegiatan penelitian, pengembangan, dan rekayasa yang dibutuhkan untuk meningkatkan kemampuan serta keterampilan, sementara pemerintah berperan mendukung kegiatan-kegiatan tersebut melalui kebijakan yang diterbitkan. Kolaborasi baik akan dapat menghasilkan inovasi teknologi pertahanan yang akan terus berkembang. Hal ini dilakukan dalam rangka meningkatkan kemandirian dan daya saing industri pertahanan.

Kesadaran bela negara sangatlah penting untuk ditanamkan kepada mahasiswa di perguruan tinggi sebagai landasan pembentukan sikap dan perilaku generasi muda bangsa Indonesia. [12] Hal ini sebagai bentuk revolusi mental sekaligus untuk membangun daya tangkal negara dalam menghadapi kompleksitas dinamika ancaman yang mungkin akan terjadi. Melalui bela negara juga akan terbangun karakter disiplin, kerja sama dan kepimpinan.

Kesadaran setiap warga negara dalam bela negara dapat diaktualisasikan dalam peran dan profesi masing-masing yang merupakan soft power bangsa bahkan akan memberikan detterence effect bagi negara lain yang ingin menganggu kedaulatan negara dan keutuhan wilayah NKRI. Karakter bela negara yang kuat harus dimiliki oleh setiap anak bangsa, terutama mahasiswa sebagai generasi muda Indonesia agar terhindar dari pengaruh-pengaruh negatif yang melemahkan nasionalismenya. Kondisi di lapangan tidak sedikit para pemuda yang terpapar paham-paham radikal. Perkembangan teknologi informasi dapat menimbulkan penetrasi nilai-nilai global termasuk faham-faham yang tidak sesuai dengan pancasila, keberadaan paham-paham radikal di Indonesia sudah selayaknya patut dicurigai dan dicegah penyebarannya.

\section{Tantangan Indonesia Kedepan}

Sejak era reformasi digulirkan tahun 1998, dari perspektif kehidupan demokrasi, kehidupan politik nasional mengalami kemajuan yang sangat signifikan. Kebebasan dan keterbukaan dalam menyampaikan pendapat, menjadi ciri kehidupan masyarakat sehari-hari. Di satu sisi, pencapaian ini tentu saja merupakan kemajuan dan prestasi besar bangsa. Namun di sisi lain, tidak dapat disangkal, bahwa keseharian kehidupan masyarakat telah diwarnai pola pikir, pola sikap dan pola tindak individualistis dan kelompok. Masyarakat luas dalam berbagai tataran, telah mengadopsi nilai-nilai baru yang belum sepenuhnya dipahami serta diyakini kebenaran dan kesesuaiannya dengan karakter bangsa. Sementara, nilai-nilai luhur bangsa dianggap sebagai nilai yang lama yang usang dan sudah tidak relevan dengan semangat reformasi yang sarat dengan semangat perubahan. Semangat perubahan telah diartikan secara hitam putih dan bahkan cenderung pragmatis tanpa memperhatikan dampak yang diakibatkannya. Situasi tersebut saat ini indonesia dihadapkan dengan berbagai pengaruh dan dampak negatif dari perkembangan lingkungan global yang disertai berubahnya persepsi dan hakikat ancaman terhadap eksistensi maupun kedaulatan negara, tentu saja hal ini harus menjadi perhatian bangsa Indonesia secara sungguh-sungguh. Indonesia kedepannya akan berhadapan dengan sistem perdagangan global baru, komunikasi dunia yang canggih, kekuatan politik yang baru, dan bentuk-bentuk ancaman yang tidak pernah dibayangkan sebelumnya. Selain itu penting bagi Indonesia untuk menyiapakan strategi yang terbaik gina menghadapi kondisi tersebut, 
mengingat kemajuan ilmu pengetahuan, teknologi informasi dan komunikasi telah berimplikasi semakin berkembangnya peperangan modern dalam bentuk Asymmetric Warfare dan Proxy War. Dunia kini juga dihadapkan dengan perang yang dilakukan oleh pihak ketiga tanpa keterlibatan langsung pihak yang berkepentingan atau disebut Proxy War.[13] Hal tersebut dilakukan oleh pihak berkekuatan besar untuk menghindari konfrontasi secara langsung dan menghindarkan terjadinya perang terbuka yang akan meninggalkan tanggung jawab besar. Andrew Mumford dalam bukunya Proxy Warfare, menyebutkan bahwa ancaman perang cyber (cyber warfare) kian membesar di masa depan seiring dengan intensnya penggunaan teknologi cyber dalam penggunaan sehari-hari. Dunia maya (cyber) kini menjadi sarana dan arena berperang yang melibatkan banyak pihak tanpa dibatasi oleh batas-batas negara. Transformasi bentuk ancaman ini, tentu harus disadari sepenuhnya oleh bangsa Indonesia, mengingat tantangan dan potensi ancaman yang semakin berat dan kompleks. Disamping tantangan dalam aspek teknologi, kini bangsa-bangsa di dunia, tengah dihadapkan pada berbagai tantangan dan isu global seperti perubahan iklim (global climate change), food security, energy security, terorisme, human security, kejahatan lintas negara (trans national crime), drug trafficking, maritime security, cyber crime, konflik di kawasan, dan lain-lain. Melihat sifat dan kompleksitas dampak yang ditimbulkannya, negara tidak lagi menjadi satu - satunya elemen yang bertanggung jawab untuk menghadapinya. Partisipasi dan peran aktif setiap individu warga negara akan menentukan keberhasilan suatu negara dalam mengantisipasi dampak negatif yang mengancam eksistensi negara dan bangsa. Untuk itulah, kalangan muda terutama mahasiswa harus menyadari bahwa sebagai salah satu komponen kekuatan nir militer, kalangan mahasiswa sebagai intelektual muda memiliki peran penting dalam mengantisipasi ancaman nir militer sesuai dengan keahlian dan kompetensi yang dimilikinya. Guna meningkatkan kemampuan sistem pertahanan di Indonesia, pengembangan teknologi alat utama sistem senjata (alutsista) merupakan sesuatu yang sangat penting, namun untuk menemukan teknologi yang muktahir diperlukan penelitian (riset) dan pengembangan (litbang) yang strategis. Untukitu melibatkan perguruan tinggi dan kaum akademisi merupakan salah satu cara terbaik guna mewujudkan hal tersebut.

\section{Intelektual Muda dan Peranannya}

Komponen Pendukung dikelompokkan dalam lima suku komponen, yakni Garda Bangsa, tenaga ahli sesuai dengan profesi dan bidang keahliannya, warga negara lainnya, industri nasional, sarana dan prasarana, serta sumber daya buatan dan sumber daya alam yang dapat digunakan untuk kepentingan pertahanan.[14] Intelektual muda menempati posisi sebagai komponen pendukung yang sangat potensial dalam mengembangkan potensi pertahanan nir militer dimana pertahanan dilakukan melalui usaha tanpa menggunakan kekuatan senjata, melainkan dengan pemberdayaan faktor-faktor ideologi, politik, ekonomi, sosial budaya, dan teknologi. Dalam masa damai maupun masa perang, sesungguhnya kalangan intelektual muda sebagai garda bangsa dalam pertahanan nirmiliter, memiliki peran yang vital dan krusial sebagai kekuatan potensial agen perubahan dalam pembentukan watak dan karakter bangsa. Di tengah tantangan perubahan yang membawa tata laku dan tata nilai baru, kalangan muda terpelajar harus mampu membekali dan membentengi diri dengan wawasan kebangsaan yang kuat. Generasi muda, utamanya para intelektual muda harus mampu memilih dan memilah tata nilai baru yang tidak sesuai dengan identitas dan jati diri bangsa yang bercirikan semangat gotong royong.

Beratnya tantangan yang dihadapi generasi muda, harus pula disikapi dengan menjaga keseimbangan antara kecerdasan intelektual dengan kecerdasan emosional maupun kecerdasan spiritual. Keseimbangan ketiga faktor tersebut, diharapkan akan mewujudkan perilaku kalangan muda yang senantiasa menjunjung tinggi moral dan etika, kejujuran dan kebangsaan. Tanpa keseimbangan ketiga faktor tersebut, kecerdasan yang dimiliki generasi muda justru akan menggerogoti sendi-sendi kehidupan bangsa. Kemampuan inilah yang sesungguhnya merupakan wujud bela negara dalam spektrum yang halus yang perlu dilakukan oleh kalangan 
muda di masa damai. Dengan disertai karakter kebangsaan yang kuat, ilmu pengetahuan, kecerdasan dan kompetensi yang dimiliki, merupakan modal utama kalangan intelektual muda untuk menjalankan kewajiban bela negaranya dalam memperkuat pertahanan negara di berbagai bidang kehidupan nasional.

Dalam perspektif Ketahanan Nasional, justru peran bela negara dalam spektrum lunak inilah yang akan menentukan kualitas pertahanan dan ketahanan bangsa kedepan. Oleh karena itu, kalangan muda harus menempatkan diri secara cerdas dan mengambil peran aktifnya dalam berbagai proses pembangunan nasional, utamanya dalam pembangunan watak dan karakter bangsa. Hal ini perlu dilakukan mengingat profesi, pengetahuan dan keahlian, serta kecerdasan yang dijiwai oleh semangat kebangsaan merupakan potensi yang dapat dimanfaatkan untuk mengelola berbagai potensi sumber daya alam secara efektif dalam membangun perekonomian nasional. Berbekal dengan potensi yang sama, kalangan muda dalam peran bela negaranya sebagai salah satu kekuatan Komponen Pendukung, dapat berpartisipasi dalam membangun kemampuan dan kemandirian industri strategis yang dibutuhkan dalam pertahanan negara.

\section{E. Bentuk Peran Perguruan Tinggi (PT) dalam Bidang Petahanan di Indonesia}

Perguruan tinggi memiliki kontribusi yang cukup besar dalam meningkatkan kualitas sumber daya manusia (SDM) di sebuah negara. Peningkata SDM ini dapat diarahkan dalam berbagai bidang, termasuk dalam bidang pertahanan negara. Mengaju pada sistem pertahanan negara yang bersifat semesta dimana melibatkan seluruh warga negara dan sumber daya nasional menjadikan keharusan bagi setiap perguruan tinggi ikut berpartisipasi dalam sistem pertahanan negara. Bentuk partisipasi tersebut dapat berupa pengembangan kemampuan bela negara maupun aplikasi ilmu pengetahuan untuk meningkatkan kemampuan alutsista pertahanan negara. Sejarah keikutsertaan Perguruan Tinggi dalam pertahan negara adalah Pada tahun 1963 dikeluarkan 3 Keputusan Bersama oleh Menteri PTIP (Mentri Pendidikan dan Kebudayaan RI tahun 1963 pada Kabinet kerja III)[15] dan WAMPAHANKAM (Wakil Menteri Pertama/Koordinator Pertahanan Keamanan tahun 1963 Kabinet Kerja III)[15] yang menggambarkan pokok pikiran pada masa itu tentang adanya tiga bentuk Dikhankamnas di lingkungan Pendidikan Tinggi yakni:Keputusan Bersama Nomor: M/A/20/163, M/A/21/1963 dan M/A/19/1963 tentang Pengaturan Mata Kuliah Pertahanan Negara ke dalam Kurikulum Perguruan Tinggi. Kemudian pada tanggal 13 November 1996 Keputusan Dirjen Dikti Depdikbud No.522/DIKTI/1996 tentang Petunjuk Pelaksanaan Pembinaan Satuan Resimen Mahasiswa di Lingkungan Perguruan Tinggi. Pada tahun 2000, di keluarkan SKB baru oleh Menham, Mendiknas, Mendagri Nomor: KB/14/M/X/2000, Nomor: 6/U/KB/2000, dan Nomor: 39 A Tahun 2000 tentang Pembinaan dan Pemberdayaan Resimen Mahasiswa.[16] Berdasarkan surat keputas bersama tentang menwa di atas maka untuk mewujudkan pertisipasi perguruan tinggi dalam bidang pengembangan SDM dan teknologi pertahanan untuk saat ini dan kedepan diperlukan suatu langkah nyata, seperti:

1. Langkah nyata yang harus ditempuh adalah :

a. mengatur regulasi bentuk agreement antara kementrian terkait yaitu antara kementrian Pendidikan Ristek, Kementrian dalam negri dengan Kementrian Pertahanan dalam bidang pengembangan SDM dan teknologi pertahanan yang mendukung sistem pertahanan negara sebagai Payung hukum yang mengikat.

b. Menggadakan Mou sebagai payung hukum antara Kementrian Keuangan, Kementrian dalam negeri dan kementrian pertahanan dalam kontribusi pendanaan pengembangan SDM dan alutsista pertahanan serta peran serta setiap daerah dalam sistem pertahanan negara.

c. Melaksanakan Perjanjian bersifat meluruh kebawah dimana bidang-bidang terkait dari kementrian tersebut di atas dengan satuan kerja yang berada dalam bidang pertahanan, seperti jajaran TNI. 
Regulasi hukum di atas berfungsi untuk mengingatkan kembali dan menjamin kesinambungan/keberlanjutan peran serta warganegara dan sumber daya nasional dalam menunaikan fungsi konstitusinya dalam bela negara. Sehingga kesadaran ini akan menjadikan suatu kekuatan bangsa indonesia dalam membangun sistem pertahanan yang kuat dan berkualitas. Perguruan tinggi sebagai wadah dan pembentuk intlektual masyarakat tentunya dapat menyadari fungsi tersebut termasuk dalam bidang pertahanan negara. Perguruan tinggi dapat menyediakan tenaga manusia, memiliki kemampuan dan kompetensi yang dibutuhkan oleh negara. Selain itu, perguruan tinggi yang berkualitas juga akan dapat mencetak pemimpin dan pemikir suatu bangsa yang mampu menentukan pembangunan negaranya di masa depan. Faktor yang menentukan dalam upaya meningkatkan kualitas perguruan tinggi antara lain : visi dan misi, aturan, pedoman tata kelola, student body, sumber daya manusia, infrastruktur, tri dharma perguruan tinggi, kerjasama internasional, visiting lecture dan isu pertahan negara secara global. Seluruh faktor tersebut merupakan dasar dalam pengelolaan perguruan tinggi. Tata kelola sebuah perguruan tinggi bergantung kepada faktor-faktor tersebut yang terintegrasi satu sama lain. Perguruan Tinggi berperan aktif dalam pembangunan sosial, yaitu sebuah proses yang lebih fokus dengan ide/gagasan dimana intervensi berlanjut dari sebuah perencanaan yang saling berhubungan dan terorganisasi.

2. Strategi-strategi pembangunan sosial dikategorikan oleh Midgley dalam tiga elemen, yang kemudian dioperasikan ke dalam tiga level di masyarakat yaitu [17]:

a) Strategi-strategi individu berfokus pada membantu orang untuk lebih bebas dan mandiri.

b) Strategi-strategi kolektif menitikberatkan pada komunitarian.

c) Pemerintah juga bertanggung jawab pada pembangunan.

Strategi yang menitik beratkan pada komunitarian inilah salah satunya setiap warganegara harus menyeimbangkan antara hak dan kewajiban. Pada UUD 1945 pasal 27 ayat (3) dan pasal 30 ayat (1) diyatakan bahwa setiap warga negara berhak dan wajib ikut serta dalam upaya pembelaan negara.

3. Implementasi yang dapat dilakukan perguruan tinggi dalam partisipasi dalam bidang pertahanan negara dalam bela negara yaitu:

a. Mengembangakan SDM berorientasi pembentukan kesadaran bela negara melalui kurikulum pendidikan wajib. Seperti yang selama ini telah dilakukan dengan memberikan pelajaran kewarganegaraan yang didalamnya terdapat pelajaran bela negara. Perlu adanya suatu peningkatan kualitas dan kuantitas pembelajaran sehingga materi yang dipelajari dapat diaplikasikan dalam kehidupan sehari-hari mahasiswa dikampus, dilingkungan keluarga dan masyarakat. Upaya mengubah sikap dan prilaku warga negara melalui mahasiswa agar selalu tanggap terhadap berbagai permasalahan negara yang dilandasi nilai-nilai bela negara sehingga terbentuk karakter nasional dimana wargan egara yang faham akan hak dan kewajibannya.

b. Membentuk unit-unit kegiatan mahasiswa (UKM) bidang bela negara. Dalam pengelolaan operasional pendidikan yang menunjang kegiatan mahasiswa perlu dibentuknya unit kegiatan mahasiswa terkait dengan bela negara. Unit kegiatan ini berfungsi sama dengan unit kegiatan mahasiswa yang lain seperti beladiri, kesenian, keagamaan, kewiraswastaan dan penelitian. UKM ini tempat mahasiswa menambah wawasan dan pengetahuan diluar kegiatan belajar, disini mereka dapat mempelajari dan memperdalam serta mempraktekkan tentang bela negara termasuk sistem pertahan negara, bahkan dapat mengembangkan minat terkait pengembangan teknologi terkait bidang pertahanan atau teknologi yang dapat mendukung sistem pertahan negara dalam suatu penelitian. Hal ini penting, selama ini UKM bela negara belum ada diperguruan tinggi, sedangkan secara kontitusi ini adalah panggilan bagi setiap warga negara. 
c. Membentuk Komunitas mahasiswa dalam pengembangan teknologi pertahanan. Dengan adanya UKM bela negara diperguruan tinggi, akan meningkatkan minat dan ketertarikan mahasiswa terhadap pengembangan sistem bela negara dan pengembangan sistem pertahanan negara melalui bidang keilmuan mereka masing-masing. Bagi yang menempuh pendidikan bidang teknik dapat berkontribusi dalam penelitian dan pengembangan teknologi bidang pertahanan. Diharapkan muncul komunitas-komunitas mahasiswa yang tertarik dalam bidang tersebut. Tentunya peran perguruan tinggi diperlukan untuk menjembatani dan memfasilitasi sarana dalam kegiatan UKM tersebut.

d. Membangun pusat studi dan sarana dalam pengembangan teknologi pertahanan. Adanya pusat-pusat studi itu dimaksudkan agar dalam pengembangan penelitian terdapat kerja sama kelembagaan dan kekhasan berdasarkan fungsinya. Fungsi pusat studi pada hakikatnya adalah sebagai wadah yang tidak hanya menampung berbagai kegiatan penelitian dan pengkajian dosen dari berbagai bidang ilmu, program studi dan fakultas di lingkungan perguruan tinggi, melainkan juga sebagai ujung tombak keberadaan dan peran perguruan tinggi tersebut terutama dalam hubungannya dengan pengembangan ilmu pengetahuan, teknologi, dan kesenian. Dengan adanya panggilan konstitusi terhadap bela negara, perguruan tinggi dapat berperan aktif mengembangkan sistem dan teknologi pertahanan negara dengan melibatkan stakeholder melalui penelitian.

e. Melibatkan praktisi sistem pertahanan dalam pengembangan teknologi pertahanan tersebut baik dalam bentuk kolaborasi penelitian, seminar ataupun kolaborasi penggunaan fasilitas dan sarana prasarana yang dibutuhkan. Implementasi Mou antar kementrian yang telah diatur sebagai regulasi Makro, dapat di teruskan tsecara mikro MoU antara Perguruan Tinggi dengan satuan kerja dan satuan pendidikan dalam jajaran kementrian pertahanan, Hal ini tentunya sangat tepat dikarenakan terkait langsung untuk kepentingan sistem pertahanan negara tersebut.

f. Membuka peluang kerjasama dengan idustri pertahanan, instansi pengguna dan Lembaga Pendidikan dalam bidang pertahanan. Bentuk kerjasama segitiga ini berguna bagi industri pertahanan dengan peran Perguruan Tinggi akan dapat meningkatkan kualitas dan kuantitas industri tersebut. Pengembangan industri pertahanan merupakan bagian terpadu dari perencanaan strategis pengelolaan sumber daya nasional untuk kepentingan pertahanan dan keamanan negara. Kerjasama ini dapat meningkatkan kemampuan memproduksi alat peralatan pertahanan dan keamanan, jasa pemeliharaan yang akan digunakan dalam rangka membangun kekuatan pertahanan dan keamanan yang ada.

g. Melakukan kerjasama dengan perguruan tinggi dan instansi dalam dan luar negri dalam pengembangan teknologi pertahanan. Presiden Jokowi dalam forum rektor Indonesia berpesan kepada perguruan tinggi agar aktif kerjasama dengan industri, buka fakultas atau departemen atau program studi di industri kawasan industri terdekat yang karakter keilmuannya dekat dengan jenis industri kawasan tersebut.[18] Hal ini tentunya termasuk industri pertahanan, bahkan perguruan tinggi ini dapat menjadi pembuka jalan kerjasama dengan perguruan tinggi luar negri dalam riset bidang teknologi yang dapat mensuport sistem pertahanan negara. Data dari IKK Ditjen dikti tentang jumlah perguruan tinggi yang bekerjasama dengan perguruan dalam dan luar negri adalah tahun 2020 terdapat 1000 kerjasama, tahun 2021 direncanakan 1.050 kerjasama dan untuk tahun 2022 rencananya 1.100 dan meningkat setiap tahunnya 50 kerjasama.[19] 


\section{KESIMPULAN}

A. Bela negara merupakan panggilan konstitusi yang telah diatur dalam UUD 1945 pada pasal 27 ayat (3) dan pasal 30 ayat (1), selain itu juga bela negara ditekankan dalam UU nomor 3 tahun 2002 pasal 9 ayat (2) tentang pertahanan negara, dimana sistem pertahanan semesta dilaksanakan dengan melibatkan seluruh warga negara, wilayah, serta segenap sumber daya nasional yang dipersiapkan secara dini oleh pemerintah dan diselenggarakan secara total, terpadu, terarah, dan berlanjut. Dalam perspektif hidup bernegara, konsep pertahanan negara dalam masa damai maupun masa perang tersebut pada dasarnya merefleksikan spektrum bela negara yang harus dipahami oleh setiap warganegara.

B. Perguruan Tinggi sebagai sumber daya nasional perlu di triggrer untuk ikut serta dalam meningkatkan dan mengembangkan bela negara dan sistem pertahanan negara melalui pembinaan sumber daya manusia dan teknologi pertahanan melalui riset dan pengembangan alutsista pertahanan baik secara mandiri ataupu bekerjasama denga stakeholder alat pertahanan tersebut.

C. Guna memudahkan dan menjaga komitmen keterlibatan Perguruan Tinggi perlu suatu regulasi yang mengatur mekanisme sistem kerjasama baik ditingkat makro yang melibatkan kementrian terkait maupun ditingkat mikro antara Perguruan tinggi dengan satuan pengguna seperti satuan operasional TNI dan lembaga pendidikan di lingkungan TNI.

D. Pada tataran pelaksanaan peran perguruan tinggi dalam bela negara dan sistem pertahanan negara perlu adanya pembentukan unit kegiatan mahasiswa guna menciptakan ketertarikan dan fokus minat mahasiswa dalam mengembangkan diri sebagai subjek bela negara dan teknologi pertahanan sebagai sarana pertananan negara dalam bela negara.

E. Pengaruh global menyebabkan mahasiswa dapat mengembangkan dirinya, dan berwawasan luas. Untuk itu perlu kerja sama antar instansi, baik swasta maupun pemerintah, baik dalam maupun luar negeri sebagai wadah dan payung hukum yang mengikat.

\section{UCAPAN TERIMA KASIH}

Saya ucapan terima kasih atas terbitnya naskah ini pada Seminar Nasional Sains Teknologi dan Inovasi Indonesia 2021 sebagai bagian kolaborasi/kerjasama penelitian dan penulisan ilmiah antar Dosen AAU yang telah terjalin selama ini. Semoga semangat untuk melaksanakan penelitian dan penulisan ilmiah ini terus berkembang dan menjadikan kebutuhan di Lembaga Pendidikan Akademi Angkatan Udara.

\section{REFERENSI}

[1] E. Setiadi, "Pengaruh Globalisasi Dalam Hubungan Internasional," hlm. 8.

[2] "Pendidikan kewarganegaraan/Sumarsono,...[et.al] | Perpustakaan Kementerian Sekretariat Negara." https://perpustakaan.setneg.go.id/index.php?p=show__diakses Nov 02, 2021).

[3] A. salim, Perubahan sosial : sketsa teori dan refleksi metodologi kasus Indonesia. Tiara Wacana Yogya, 2002. [Daring]. Tersedia pada: https://catalogue.nla.gov.au/Record/541400

[4] Sekretaris Negara RI, "Penjelasan Undang undang Republik Indonesia Nomor 3 tentang Pertahanan Negara." [Daring].: https://www.dpr.go.id/dokjdih/document/uu/300.pdf

[5] 2002. [Daring]. Tersedia pada: https://id.wikisource.org/wiki/Undang-Undang_Republik_Indonesia_ 
[6] "Peraturan Presiden (PERPRES) Nomor 7 tentang Kebijakan Umum Pertahanan Negara." 26Januari 2008. [Daring]. Tersedia pada: https://peraturan.bpk.go.id/Home/Details/42194/perpres-no-7-tahun2008

[7] UGM, “, Sistem Pendidikan Nasional Untuk Membangun Peradaban Bangsa Indonesia yang dijiwai Nilai-Nilai Pancasila, Yogyakarta,” hukumonline.com, 2007. https://hukumonline.com/pusatdata/detail/331/node/539/undangundang-nomor-3-tahun-2002/ (diakses Nov 02, 2021).

[8] Inspektorat Jenderal Kemhan RI. Diakses: Nov 02, 2021. [Daring]. Tersedia pada: https://www.kemhan.go.id/itjen/2016/02/12/buku-putih-pertahanan-indonesia-tahun-2014.html

[9] "Komponen Cadangan Hanya untuk Kepentingan Negara," 102021. https://kominfo.go.id/content/detail/37394/presiden-komponen-cadangan-hanya-untuk-kepentingannegara/0/berita

[10] "Sosialisasi Tataran Dasar Bela Negara Pada Dasarnya Adalah Sebagai Suatu Upaya Memberikan Pengetahuan Yang Pada Akhirnya Dapat Mewujudkan Sikap Dan Perilaku Bela Negara Yang Dilandasi Wawasan Kebangsaan | PDF," Scribd. https://id.scribd.com/doc/39633972/SosialisasiTataran-Dasar-Bela-Negara (diakses Nov 02, 2021).

[11] Anonim, Jakarta, 2012.

[12] "Pembinaan Kesadaran Bela Negara Bagian Upaya Membangun Sistem Pertahanan Negara." http://www.dmcindonesia.web.id/modules.php

[13] Kementrian Pertahanan, Bahan Pembelajaran Proxy War, Kep/1016/XI/2020. Kementrian Pertahanan, 2020.

[14] "Nasionalisme dan Bela Negara dalam Perspektif Ketahanan Nasional.” https://www.kemhan.go.id (diakses Nov 14, 2021).

[15] "Daftar Menteri Pendidikan dan Kebudayaan Republik Indonesia sejak 1945 - Sekarang," Jan 20, 2020. https://www.quipper.com/id/blog/tips-trick/school-life/daftar-menteri-pendidikan-dankebudayaan-republik-indonesia-sejak-1945-sekarang/amp/

[16] A. Gelz, "Implementasi Bela Negara Di Lingkungan Mahasiswa Melalui Organisasi MENWA,” Jan 19, 2010. https://cikumsworld11.blogspot.com/2010/01/implementasi-bela-negara-dilingkungan.html

[17] S. A. Nulhaqim, D. H. Heryadi, R. Pancasilawan, dan M. Ferdryansyah, "Peranan Perguruan Tinggi Dalam Meningkatkan Kualitas Pendidikan Di Indonesia Untuk Menghadapi Asean Community 2015 Studi Kasus: Universitas Indonesia, Universitas Padjadjaran, Institut Teknologi Bandung," Share Soc. Work J., vol. 6, no. 2, Art. no. 2, Des 2016, doi: 10.24198/share.v6i2.13209.

[18] "Empat Pesan Jokowi pada Forum Rektor Indonesia," Jul 04, 2020. https://www.republika.co.id

[19] "Renstra-Dikti-2020-2024-rev-3.1.pdf," 2020. https://dikti.kemdikbud.go.id/wpcontent/uploads/2021/08/ 